\title{
Rzeźba strukturalna obszaru Świętokrzyskiego Parku Narodowego
}

\author{
Adam Lajczak ${ }^{1}$, Jan Urban ${ }^{2}$, Zofia Rączkowska ${ }^{3}$, Grzegorz Wałek ${ }^{4}$
}

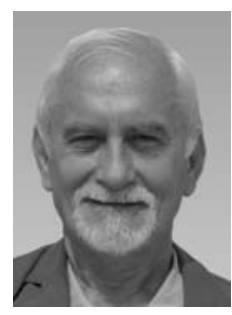

A. Łajczak

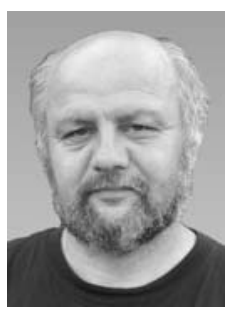

J. Urban

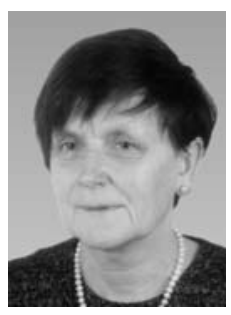

Z. Rączkowska

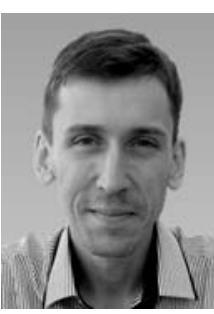

G. Wałek

Structural morphology of the area of the Świętokrzyski National Park. Prz. Geol., 68: 102-111; doi: $10.7306 / 2020.3$

A b s tract. The area of the S'więtokrzyski National Park is one of the most evident examples of structural morphology in Poland. Its relief is clearly determined by bedrock lithology: the hill ranges are composed of hard quartzitic sandstones of the upper Cambrian (Eysogóry Range) and the Lower Devonian (Klonowskie Range), while the depressions, usually vast and flat-bottomed, are distributed on outcrops of soft, easily weathered and eroded Ordovician and Silurian shales, greywackes and sandstones. The parallel pattern of hill ranges and depressions, as well as a mesh-grid pattern of river valley systems and the antecedent character of river gaps, reflects fold tectonics modified by transverse faults. Such a morphology developed during the Paleogene and Neogene under hot and then warm, gradually cooling climatic conditions. In the Pleistocene, principally under the periglacial conditions, block fields (symbols of the Świętokrzyski NP) and crags (crests, table-like forms, cupolas and spurs) were formed. The shape and spatial position of most crags are related to geological structures.

Keywords: structural morphology, hill ranges, block fields, crags, Świętokrzyskie (Holy Cross) Mountains

Rzeźba obszaru Świętokrzyskiego Parku Narodowego (ŚPN) i jego najbliższego otoczenia od ponad 80 lat stanowi przedmiot badań z zakresu geologii i geomorfologii. Była jedną $\mathrm{z}$ istotnych przesłanek przemawiających za objęciem tego terenu prawną ochroną przyrody (Czarnocki, 1928). Wyniki badań geomorfologicznych ŚPN są zawarte w licznych publikacjach, w większości odnoszących się do najwyżej wzniesionego obszaru w Parku - Łysogór (Lencewicz, 1934, 1936, 1957a, b; Klimaszewski, 1958; Klatka, 1962, 1965; Radłowska, 1967, 1968; Gilewska, 1972; Wróblewski, 1976; Kowalski, 1995a, b, 2000; Kondracki, 2000). Autorzy dotychczasowych publikacji, dotyczących morfologii obszaru parku, podkreślają jej bardzo wyraźną zależność od budowy geologicznej i tektoniki, a więc strukturalny typ rzeźby (Urban, 2014).

Niniejszy artykuł podsumowuje rezultaty dotychczasowych badań, został uzupełniony o wyniki kartowania geomorfologicznego i terenowych obserwacji autorskich, dokonanych na przełomie XX i XXI w. oraz w pierwszych kilkunastu latach XXI w. Badania te były prowadzone przede wszystkim w ramach przygotowywania (niepublikowanych) Operatów Geomorfologicznych Planu Ochrony Świętokrzyskiego Parku Narodowego (Rączkowska, Rączkowski, 1999; Łajczak, 2014), a także podczas realizacji projektów badawczych finansowanych przez MNiSW (grant nr 2PO4E04929 dotyczący badań form skałkowych w regionie świętokrzyskim - J. Urban). W opracowaniach dotyczących ochrony parku szczególną uwagę zwrócono na zagrożenia form i procesów geomorfologicznych na terenie ŚPN oraz na rolę antropogenicznych czynników w kształtowaniu rzeźby jego obszaru (co wynikało bezpośrednio z celu powstania opracowań do Planu Ochrony ŚPN). Aspekty te były dotąd stosunkowo rzadko przedmiotem analiz na tym obszarze. Oprócz prac terenowych, dodatkowym materiałem wykonanym ostatnio w celu bardziej precyzyjnego opisu cech morfologii obszaru ŚPN, jest analiza map cyfrowych powierzchni parku oraz przekrojów poprzecznych przez stoki najwyższych pasm wzniesień (G. Wałek). Wyniki dawnych oraz najnowszych prac badawczych zebrano w związku z przygotowywaniem monografii ŚPN, która ma zostać wydana w 70. rocznicę jego utworzenia przypadającą w $2020 \mathrm{r}$.

\section{SYTUACJA GEOLOGICZNA I GEOMORFOLOGICZNA OBSZARU ŚWIĘTKRZYSKIEGO PARKU NARODOWEGO}

Obszar Świętokrzyskiego Parku Narodowego jest położony w obrębie północnej, łysogórskiej części trzonu paleozoicznego Gór Świętokrzyskich (łysogórska strefa fałdów - Konon, 2008), który należy do wschodniej części antyklinorium śródpolskiego, zwanej antyklinorium szydłowieckim (Karnkowski, 2008; Jarosiński i in., 2009). Mniej więcej wzdłuż południowej granicy parku biegnie uskok świętokrzyski - ponadregionalna strefa dyslokacyjna oddzielająca części łysogórską i kielecką trzonu paleozoicznego, które różnią się od siebie zarówno historią rozwoju geologicznego (brak lub obecność utworów, odmienne litologicznie formacje geologiczne), jak i tektoniką. Podłoże parku jest zbudowane z utworów starszego

\footnotetext{
${ }^{1}$ Instytut Geografii, Uniwersytet Pedagogiczny im. Komisji Edukacji Narodowej w Krakowie, ul. Podchorążych 2, 30-084 Kraków; alajczak@o2.pl

${ }^{2}$ Instytut Ochrony Przyrody Polskiej Akademii Nauk, al. Adama Mickiewicza 33, 31-120 Kraków; urban@iop.krakow.pl

${ }^{3}$ Zakład Badań Geośrodowiska, Instytut Geografii i Przestrzennego Zagospodarowania, Polska Akademia Nauk, ul. Św. Jana 22, 31-018 Kraków; raczk@zg.pan.krakow.pl

${ }^{4}$ Instytut Geografii, Uniwersytet Jana Kochanowskiego w Kielcach, ul. Świętokrzyska 15, 25-406 Kielce; grzegorz.walek@gmail.com
} 
paleozoiku: osadowych skał kambru górnego (lokalnie słabo zmetamorfizowanych - Salwa, 2006), ordowiku, syluru oraz dewonu (ryc. 1). Utwory kambryjskie tworza tzw. fałd łysogórski (fałd Łysicy) - strukturę antyklinalną, która w kierunku północnym przechodzi w synklinę bodzentyńską, zbudowaną w strefie osiowej z utworów dewońskich. Te głównie waryscyjskie struktury uległy późniejszym, alpejskim deformacjom, zaś część autorów (Kowalczewski, 2000a, b) dopatruje się w nich także kaledońskich elementów tektonicznych (Czarnocki, 1950, 1957; Filonowicz, 1962, 1966, 1968, 1969; Mastella, Mizerski, 2002; Mizerski, 1991, 2004; Graniczny i in., 2005; Nawrocki i in., 2007; Urban, Gagol, 2008; Narkiewicz $i$ in., 2010).

Kambr jest reprezentowany przede wszystkim przez górnokambryjską formację piaskowców z Wiśniówki, zbudowaną z piaskowców kwarcytowych przewarstwionych pakietami łupkowymi i piaskowcowo-łupkowymi o łącznej miąższości co najmniej kilkuset metrów (ryc. 2). W podłożu i nadkładzie tej formacji występują utwory łupkowe i łupkowo-piaskowcowe, odpowiednio kambru środkowego i górnego (Kowalczewski i in., 2006). W dolnej części profilu ordowiku i syluru, których łączna miąższość przekracza $1000 \mathrm{~m}$, dominują utwory ilasto-mułowcowe, natomiast w górnej jego części znaczny udział mają szarogłazy i piaskowce szarogłazowe (Malec, 2006; Trela, 2006). Dewon w granicach ŚPN jest reprezentowany przede wszystkim przez serie piaskowcowe przewarstwione seriami ilastymi, które należą do dolnodewońskich formacji barczańskiej i zagórzańskiej (ryc. 1, 2) (Szulczewski, 1995; Narkiewicz i in., 2006). Otulina ŚPN przekracza uskok świętokrzyski, obejmując fragment wychodni kieleckiej strefy fałdów, a także wkracza miejscami na teren wychodni skał permskich i triasowych permsko-mezozoicznego obrzeżenia Gór Świętokrzyskich (Czarnocki, 1950; Filonowicz, 1962, 1966, 1968, 1969; Walczowski, 1968; Kowalczewski, 2000a, b; Kowalczewski, Kowalski, 2000; Urban, Gagol, 2008).

W podziałach geograficznych ŚPN zajmuje centralną część Gór Świętokrzyskich, które mają rangę mezoregionu (Solon i in., 2018) (ryc. 1) i których morfologiczną dominacją jest Pasmo Łysogórskie o przebiegu WNW-ESE, z kulminacjami w części zachodniej, w masywie Łysicy (Skałka Agaty - 613,7 m n.p.m., Łysica - 612,4 m n.p.m.;

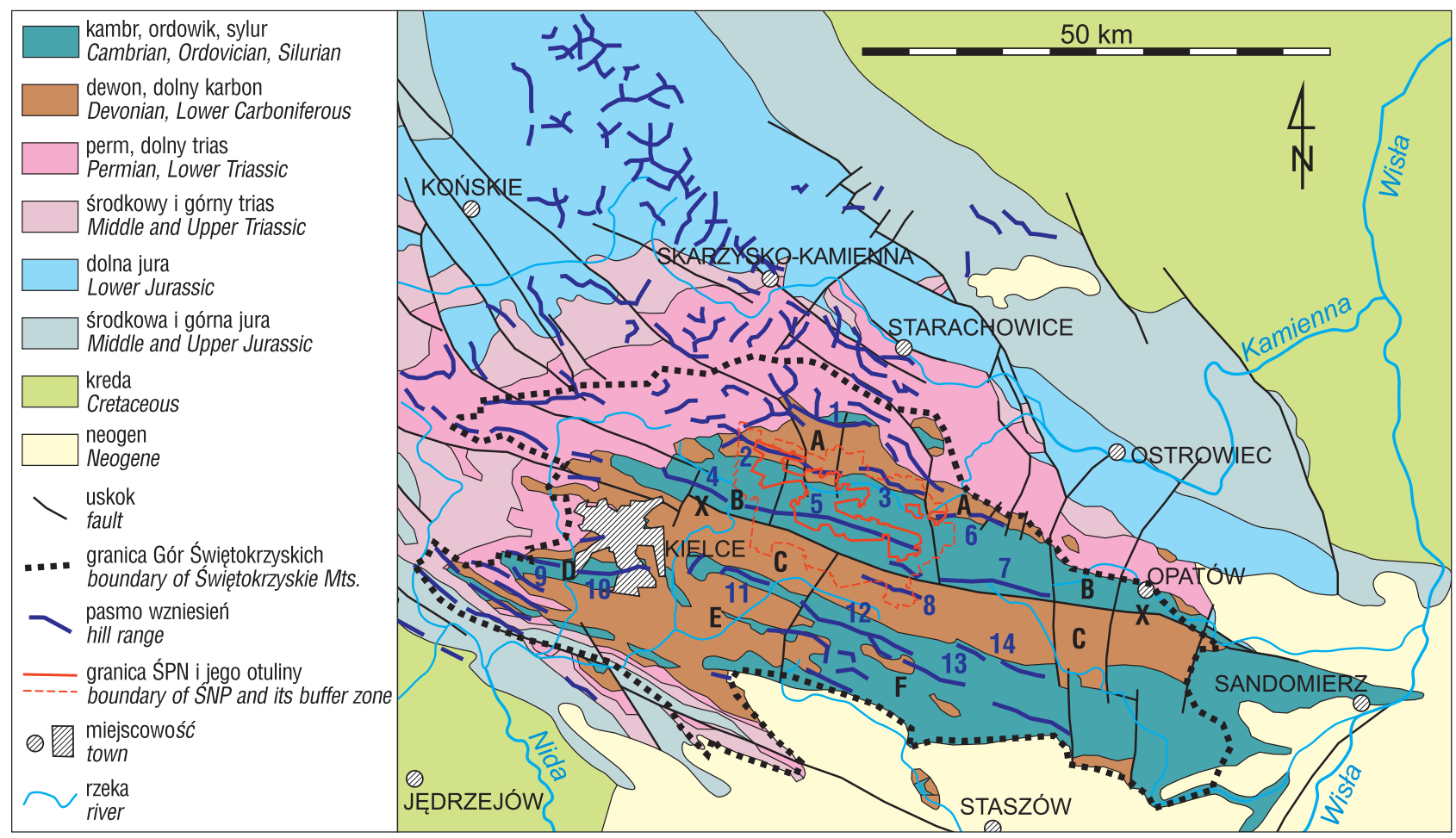

Ryc. 1. Świętokrzyski Park Narodowy na tle głównych struktur geologicznych oraz geograficznego podziału mezoregionu Gór Świętokrzyskich (mapa geologiczna na podstawie: Wróblewskiego, 2000a, zmodyfikowana wg Konona, 2008; pasma wzniesień wg Wróblewskiego, 1976; granice mezoregionu wg Solona i in., 2018). Objaśnienia symboli literowych - ważniejsze elementy geologiczne w obrębie i najbliższym otoczeniu parku: A - synklina bodzentyńska, B - antyklina łysogórska (Łysicy), C - synklinorium kielecko-łagowskie, D - antyklina dymińska, E - synklina bolechowicka, F - synklina bardziańska, X - uskok świętokrzyski. Objaśnienia symboli cyfrowych - pasma wzniesień na terenie parku i w jego najbliższym otoczeniu: 1 - Pasmo Sieradowickie, 2 - Pasmo Klonowskie, 3 - Pasmo Bostowskie, 4 - Pasmo Masłowskie, 5 - Pasmo Łysogórskie, 6 - Pasmo Pokrzywiańskie, 7 - Pasmo Jeleniowskie, 8 - Pasmo Bielińskie, 9 - Pasmo Zgórskie, 10 - Pasmo Posłowickie i Dymińskie, 11 - Pasmo Brzechowskie, 12 - Pasmo Orłowińskie, 13 - Pasmo Wygiełzowskie, 14 - Pasmo Iwaniskie

Fig. 1. Świętokrzyski National Park against principal elements of geology and the geographical division of the meso-region of the Świętokrzyskie (Holy Cross) Mountains (geological map after Wróblewski, 2000a, modified after Konon, 2008; hill ranges after Wróblewski, 1976; limit of the meso-region after Solon et al., 2018). Explanation of letter symbols - principal tectonic structures of the Park area and its vicinity: A - Bodzentyn Syncline, B - Łysogóry (Łysica) Anticline, C - Kielce-Łagów Synclinorium, D - Dyminy Anticline, E - Bolechowice Syncline; F - Bardo Syncline, X - Świętokrzyski Fault. Explanation of number symbols - hill/mountain ranges within the Park area and its vicinity: 1 - Sieradowickie Range, 2 - Klonowskie Range, 3 - Bostowskie Range, 4 - Masłowskie Range, 5 - Łysogórskie Range, 6 - Jeleniowskie Range, 7 - Bielińskie Range, 8 - Zgórskie Range, 9 - Posłowickie and Dymińskie Range, 10 - Brzechowskie Range, 11 - Orłowińskie Range, 12 - Wygiełzowskie Range, 13 - Iwaniskie Range 


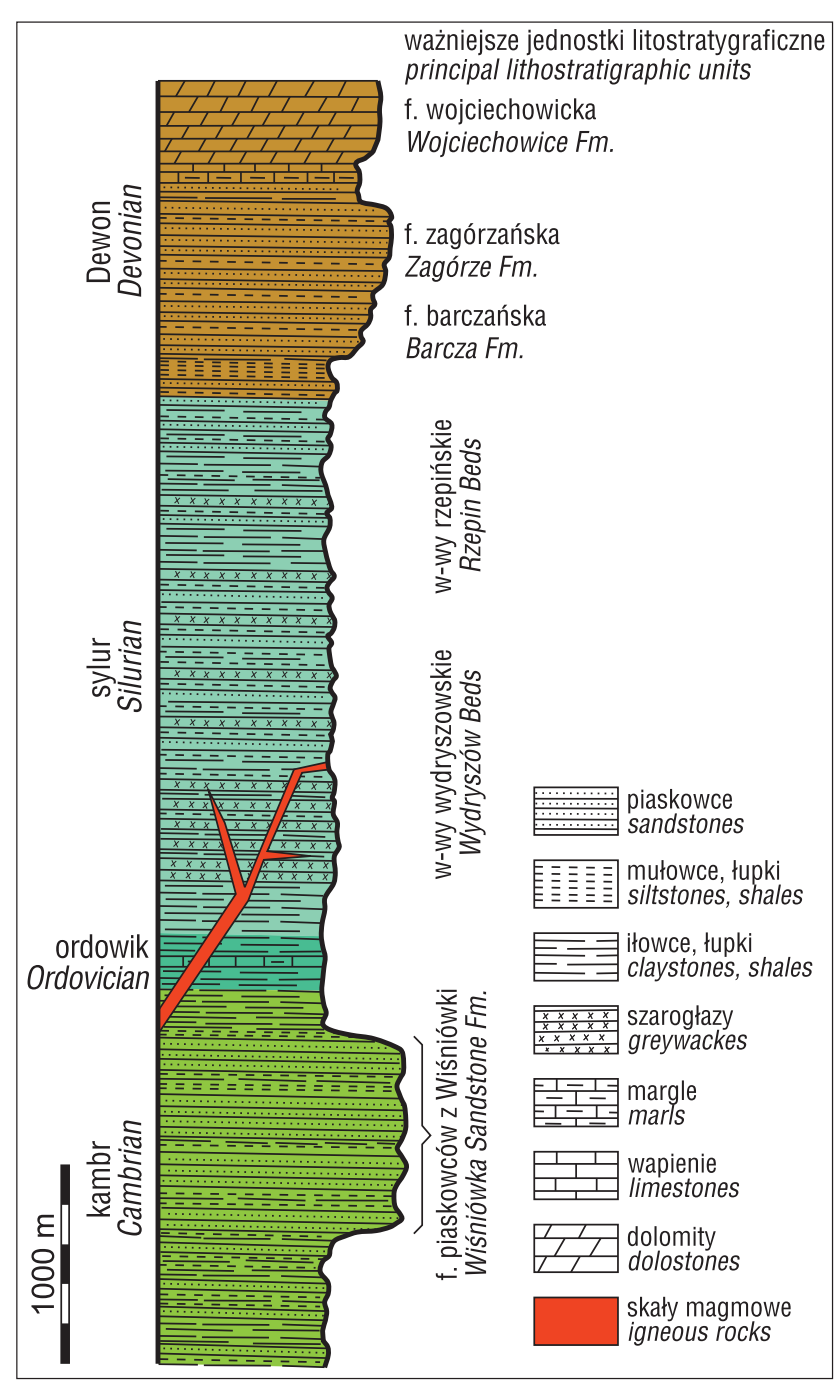

Ryc. 2. Schematyczny profil litostratygraficzny ilustrujący zróżnicowanie odporności poszczególnych jednostek litostratygraficznych na obszarze ŚPN i otuliny (wg Filonowicza, 1962, 1966 oraz opisów w: Kowalczewski i in., 2006; Trela, 2006; Narkiewicz i in., 2006)

Fig. 2. Schematic litostratigraphic sequence illustrating differentiation of hardness of particular litostratigraphic units within the area of the ŚNP (after Filonowicz, 1962, 1966 and descriptions in Kowalczewski et al., 2006; Trela, 2006; Narkiewicz et al., 2006)

Hajdukiewicz, Romanyszyn, 2017) oraz w części wschodniej (Łysiec zwany też Łysą Górą - 595 m n.p.m.). Wraz z Pasmem Jeleniowskim, stanowiącym jego przedłużenie ku wschodowi, oraz Pasmem Masłowskim, czyli przedłużeniem zachodnim, Pasmo Łysogórskie tworzy Grzbiet Główny stanowiący oś morfologiczną Gór Świętokrzyskich (ryc. 1), zbudowany z górnokambryjskich skał formacji piaskowców z Wiśniówki (Gilewska, 1991; Kondracki, 2000; Wróblewski, 2000a). Pasmo Łysogórskie i Pasmo Jeleniowskie spełniają kryteria gór niskich, gdyż ich wysokość bezwzględna przekracza 500 m n.p.m., zaś wysokość względna jest większa od 300 m (Starkel, 1972; Slaymaker, 2004).

Pasmo Łysogórskie sąsiaduje od północy z równolegle biegnąca, subsekwentną Doliną Wilkowską i stanowiącą jej przedłużenie ku wschodowi Doliną Dębniańską, których podłoże tworzą utwory ordowiku i syluru. Po północnej stronie tych dolin występuje Pasmo Klonowskie i dalej ku wschodowi Pasmo Bostowskie i Pasmo Pokrzywiańskie, zbudowane $\mathrm{z}$ odpornych piaskowców dewońskich i uformowane jako zwarte grzbiety lub izolowane pagóry. Od południa do Pasma Łysogórskiego przylega Obniżenie Kielecko-Łagowskie wypreparowane w skałach dewońskich i dolnokarbońskich (ryc. 1, 3), gdzie wyróżnia się Pasmo Bielińskie i góra Strużna, zbudowane z piaskowców dewońskich, oraz Pasmo Brzechowskie $-\mathrm{z}$ wapieni i dolomitów dewońskich.

Świętokrzyski Park Narodowy obejmuje najwyżej wzniesiony fragment Pasma Łysogórskiego zwany Łysogórami (patrz okładka tego numeru Przegladu Geologicznego), który rozciąga się między Przełęczą Krajeńską na zachodzie a rzeką Słupianką na wschodzie na odcinku $16 \mathrm{~km}$. W granicach ŚPN znajdują się także duże fragmenty Doliny Wilkowskiej i Doliny Dębniańskiej, wschodnia część Pasma Klonowskiego oraz niewielkie fragmenty Pasma Pokrzywiańskiego (ryc. 1).

Teren parku i jego otuliny jest na przeważającym obszarze wzniesiony w przedziale wysokości 250-350 m n.p.m., gdzie dominują doliny i podnóża stoków pasm. Na tym obszarze przeważają spadki terenu mniejsze od $6^{\circ}$. Nachylenia terenu większe od $15^{\circ}$ są typowe tylko dla pasm twardzielowych, wzniesionych powyżej $350 \mathrm{~m}$ n.p.m. Prawie równoleżnikowy przebieg wzniesień i obniżeń na obszarze ŚPN i otuliny skutkuje dominacją północnej i południowej ekspozycji form terenu.

\section{STRUKTURALNE ZAŁOŻENIA GLÓWNYCH RYSÓW RZEŹBY}

Morfologia obszaru Świętokrzyskiego Parku Narodowego i otuliny ma typowe cechy rzeźby strukturalnej odzwierciedlającej budowę geologiczną podłoża. Głównymi elementami rzeźby są pasma wzniesień wykształcone na wychodniach skał najbardziej odpornych na denudację: górnokambryjskich i dolnodewońskich piaskowców kwarcytowych, oraz oddzielające je obniżenia w miejscach występowania skał o mniejszej odporności na wietrzenie i erozję: ordowickich oraz sylurskich łupków i szarogłazów (ryc. 2). Pasma wzniesień układają się równolegle, rusztowo i mają wydłużenie WNW-ESE, zgodne z przebiegiem fałdowych struktur tektonicznych w podłożu oraz warunkowanych nimi wychodni skał (ryc. 3) (Radłowska, 1967, 1968; Gilewska, 1972, 1991; Wróblewski, 1976; Kowalczewski i in., 1989; Kondracki, 2000; Kowalczewski, 2000a, b; Kowalczewski, Kowalski, 2000). Taka rzeźba jest wynikiem selektywnej denudacji w paleogenie oraz neogenie, szybszej na wychodniach skał, które w warunkach klimatu gorącego i później ciepłego, jaki wówczas panował na tym terenie, były mniej odporne na wietrzenie i erozję (Klimaszewski, 1958; Klatka, 1965; Olędzki, 1976; Kowalski, 1995b, 2000; Urban, 2014).

Pasma na obszarze ŚPN i jego otuliny mają budowę izoklinalną, przy czym w Łysogórach upad warstw jest większy niż nachylenie stoków, natomiast w przypadku Pasma Klonowskiego upad warstw jest bardzo zbliżony do nachylenia północnego stoku pasma (Kowalczewski i in., 1989; Kowalski, 2000; Kowalczewski, 2000a, b; Kowalczewski, Kowalski, 2000). Stoki obu pasm o ekspozycji NNE są bardziej strome niż stoki południowe (SSW) (ryc. 4). Te ostatnie są głębiej rozczłonkowane niszami źródłowymi. Na południowym stoku Łysogór lokalnie jest uformowany wyraźny załom (spłaszczenie), miejscami przechodzący w osobny równoległy grzbiet lub lokalne kulminacje (ryc. 3). Na tym stoku występują także zestromienia o zróżnicowanej wysokości względnej, których genezę tłumaczy się tek- 


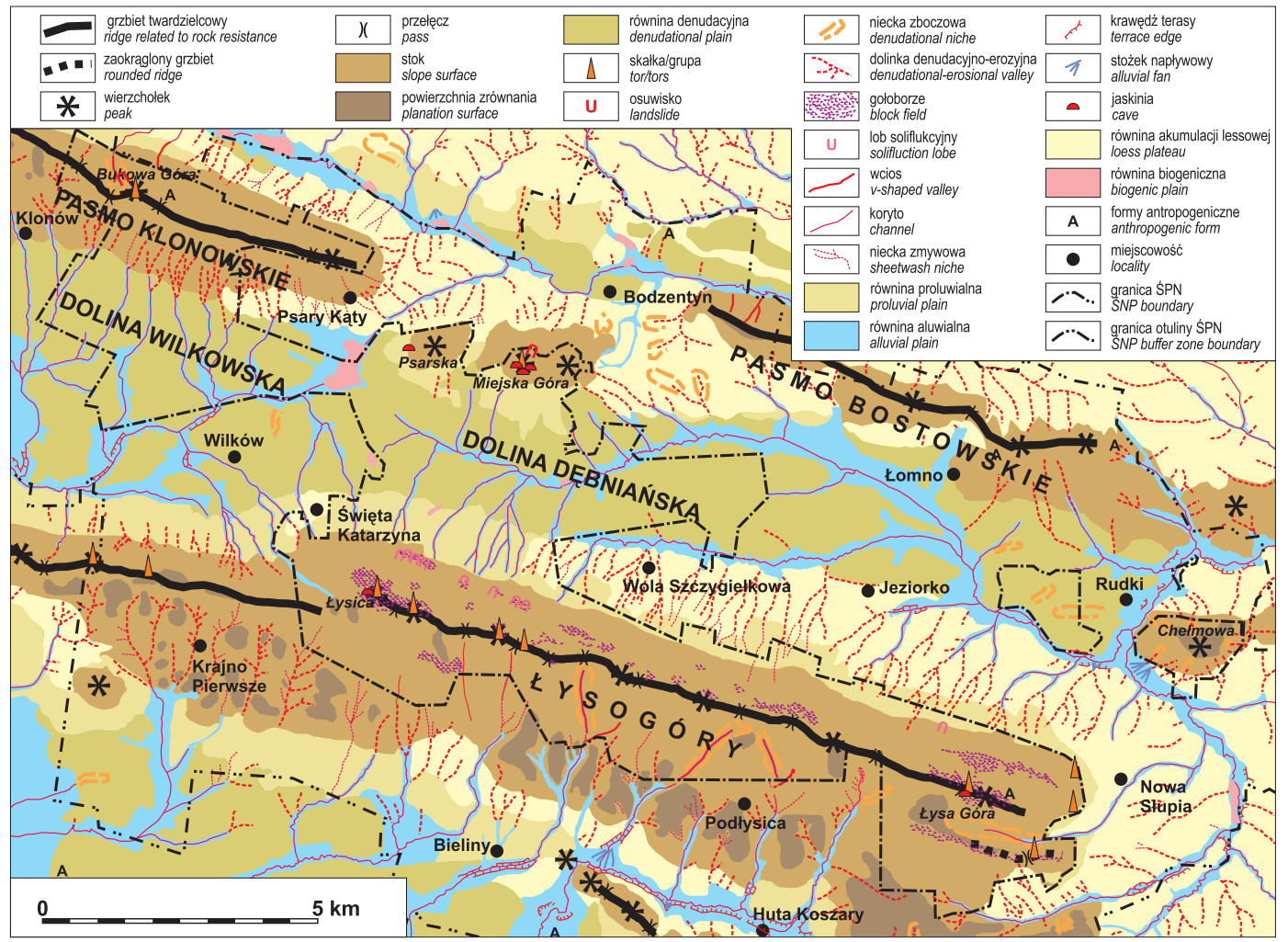

Ryc. 3. Mapa geomorfologiczna Świętokrzyskiego Parku Narodowego

Fig. 3. Geomorphological map of the Świętokrzyski National Park

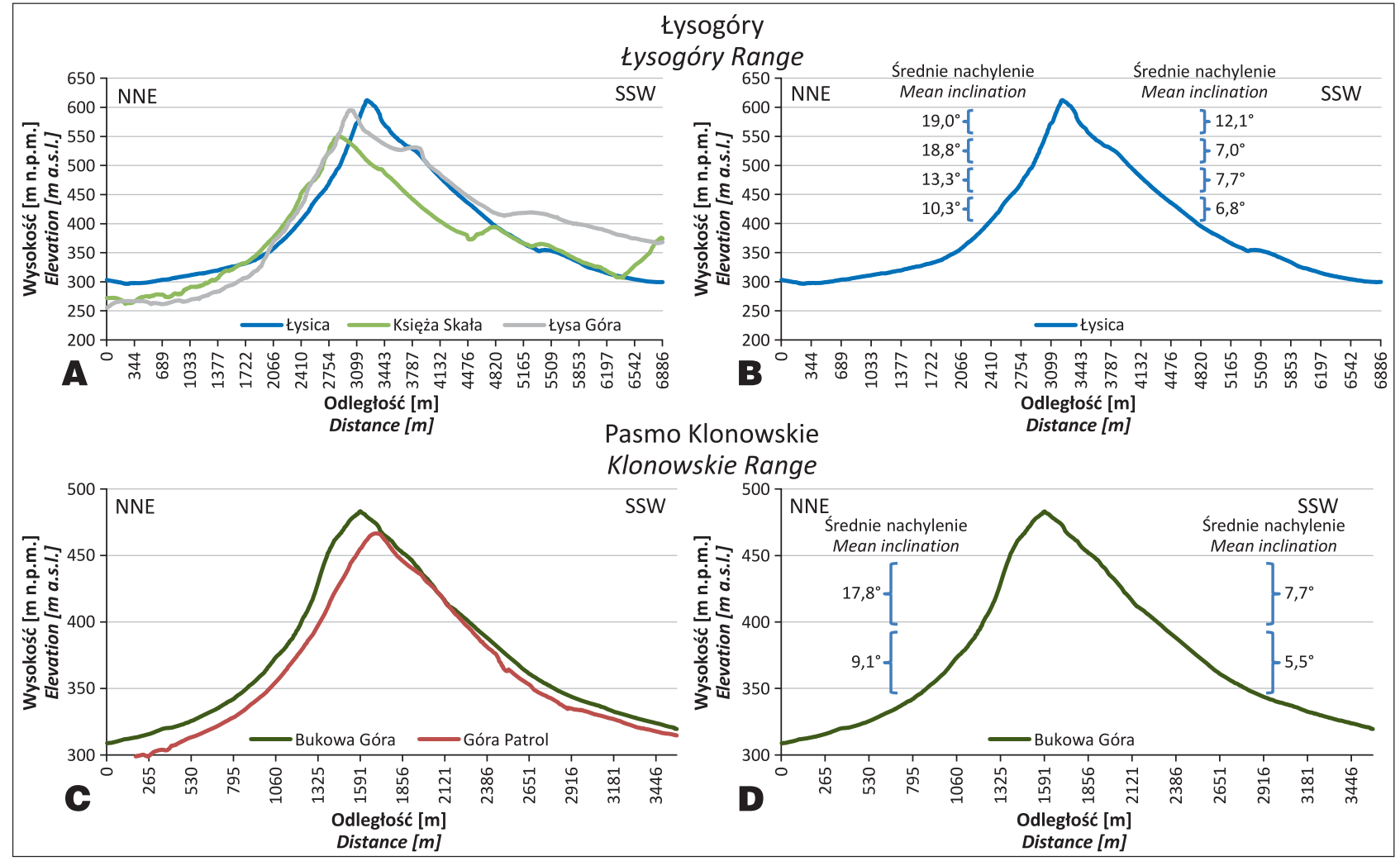

Ryc. 4. Morfologiczne profile poprzeczne Łysogór i Pasma Klonowskiego. A - profile poprzeczne przez główne szczyty Łysogór; B - średnie nachylenie stoków w 50-metrowych interwałach wysokościowych na północnym i południowym stoku Łysicy; $\mathbf{C}$ - profile poprzeczne przez główne szczyty Pasma Klonowskiego; D - średnie nachylenie stoków w 50-metrowych interwałach wysokościowych na północnym i południowym stoku Bukowej Góry

Fig. 4. Morphological cross-sections of the Łysogóry Range and the Klonowskie Range. A-transverse profiles through the main peaks of the Łysogóry Range; $\mathbf{B}$ - mean slope inclination at $50 \mathrm{~m}$ elevation intervals on the northern and southern slopes of $Ł y$ sica; $\mathbf{C}$ - transverse profiles through the main peaks of the Klonowskie Range; D - mean slope inclination at $50 \mathrm{~m}$ elevation intervals on the northern and southern slopes of Bukowa Góra 
tonicznym przesunięciem wychodni serii piaskowców. Pasy zestromień i spłaszczeń obserwuje się także na północnym stoku Łysogór. Takie zróżnicowanie profilu stoków tłumaczy się uwarunkowaniami strukturalnymi, czyli obecnością w podłożu sąsiadujących z sobą wychodni mniej i bardziej odpornych serii piaskowcowych, piaskowcowo-łupkowych i łupkowych. Z kolei studium rzeźby Pasma Klonowskiego sugeruje paleogeograficzne uwarunkowania spłaszczeń na południowym stoku pasma - ich związek z etapami wznoszenia i stabilizacji tektonicznej tego elementu rzeźby w kenozoiku (Klatka, 1962; Kowalski, Jaśkowski, 1986; Kowalczewski i in., 1989, 2000; Kowalczewski, 2000a, b).

Średnie nachylenia północnego skłonu Łysogór w profilu Łysicy zwiększają się ze wzrostem wysokości od $10^{\circ}$ w obrębie podnóży, do $13^{\circ} \mathrm{w}$ środkowej części stoku i do $19^{\circ}$ (lokalnie do $30^{\circ}$ ) w jego górnych partiach. Nachylenia południowego skłonu tego pasma są mniejsze i wynoszą odpowiednio: 7,8 i $12^{\circ}$ (maksymalnie $25^{\circ}$ ). Nachylenia stoków Pasma Klonowskiego w profilu Bukowej Góry w przypadku skłonu północnego wzrastają od $9^{\circ} \mathrm{w}$ obrębie podnóży do $18^{\circ}$ (lokalnie do $25^{\circ}$ ) w górnej części stoku, a w przypadku skłonu południowego wynoszą odpowiednio 5 i $8^{\circ}\left(\right.$ do $\left.13^{\circ}\right)$ (ryc. 4$)$.

Różnice między ukształtowaniem północnego i południowego skłonu Łysogór, a także Pasma Klonowskiego, wyrażono za pomocą krętości poziomic. Prostolinijny przebieg poziomic na stoku pozbawionym nisz czy załomów innej genezy wyrażono wartością 1,0 (iloraz długości poziomicy i odcinka łączącego skrajne punkty poziomicy). Im większa wartość ilorazu tym przebieg poziomicy jest bardziej kręty (ryc. 5). Na północnym skłonie Łysogór, o kierunku nachylenia zgodnym $\mathrm{z}$ upadem warstw piaskowców kambryjskich, gdzie brak jest wklęsłych form terenu, kolejne poziomice (co $50 \mathrm{~m}$ ) od 300 do $550 \mathrm{~m}$ n.p.m. mają krętość zmieniającą się tylko w zakresie od 1,25 do prawie 1,00. Na południowym skłonie, gdzie w profilu wysokościowym odsłaniają się warstwy skalne o zróżnicowanej odporności i są uformowane głębokie nisze oraz lokalnie spłaszczenia stokowe, w tym samym przedziale wysokości n.p.m. krętość poziomic jest znacznie większa i mieści się w przedziale 1,60-1,20. Podobne prawidłowości stwierdzono na północnym i południowym skłonie wschodniej części Pasma Klonowskiego (w strefie wysokości 300-450 m n.p.m.), gdzie krętość poziomic zawiera się wprzedziałach 1,25-1,15 dla stoku północnego i 1,40-1,10 dla południowego.

Między Łysogórami na południu a Pasmem Klonowskim na północy w kierunku WNW-ESE rozciąga się Dolina Wilkowska, położona na wysokości ok. 290-340 m n.p.m., której szerokość wynosi od 3 do $5 \mathrm{~km}$. Kontynuacją tej doliny w kierunku wschodnim jest, leżąca ok. $50 \mathrm{~m}$ niżej, Dolina Dębniańska o takim samym przebiegu i zbliżonej szerokości, położona między Łysogórami na południu a górą Psarską i Pasmem Bostowskim na północy (ryc. 3). Obie doliny są wycięte $\mathrm{w}$ łupkach i słabo zwięzłych szarogłazach sylurskich dlatego ich dna mają monotonną rzeźbę $\mathrm{z}$ nachyleniami terenu najczęściej mniejszymi od $1^{\circ}$. Taka rzeźba sprzyja powstawaniu terenów podmokłych - Dolinę Wilkowską od Doliny Dębniańskiej oddziela południkowo biegnący dział wodny między zlewniami Lubrzanki i Pokrzywianki, w najniższym położeniu topograficznym trudno zauważalny na płaskim, miejscami pod-

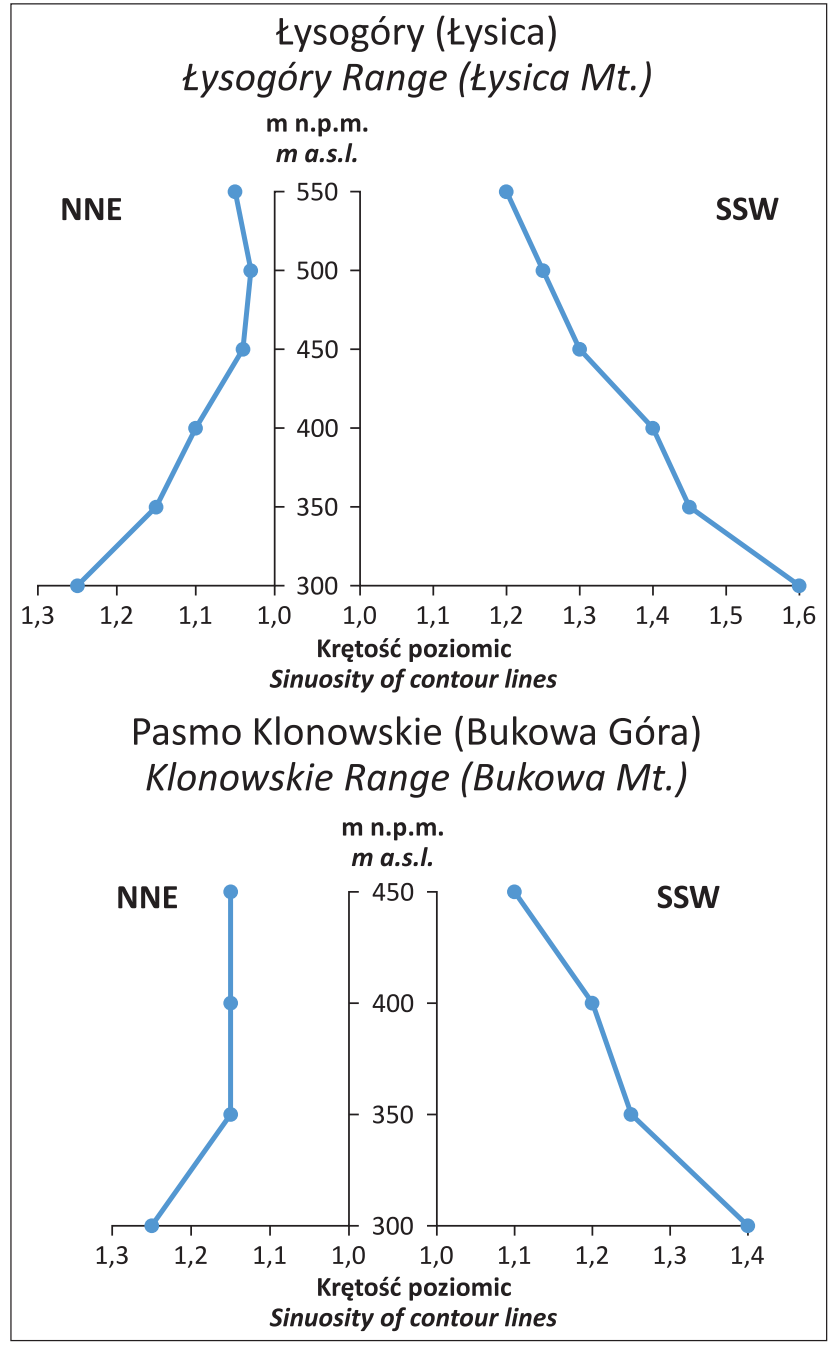

Ryc. 5. Krętość poziomic (co $50 \mathrm{~m}$ ) na północnym i południowym skłonie Łysogór (Łysica) oraz wschodniej części Pasma Klonowskiego (Bukowa Góra)

Fig. 5. Sinuosity of contour lines (every $50 \mathrm{~m}$ ) on the northern and southern slopes of the Łysogóry Range (Łysica Mt.) and the eastern part of the Klonowskie Range (Bukowa Mt.)

mokłym terenie (Mokry Bór) (Rączkowska, Rączkowski, 1999; Łajczak, 2014).

\section{ROLA TEKTONIKI W ZRÓŻNICOWANIU WYSOKOŚCI WZGLĘDNYCH I W PRZEBIEGU GRZBIETÓW}

Oprócz elementu litologicznego, czynnikiem zwiększającym różnice wysokościowe pomiędzy wyniesionymi i obniżonymi elementami terenu mogły być również pionowe ruchy tektoniczne w erze kenozoicznej, które powodowały wynoszenie lub obniżanie poszczególnych elementów (bloków tektonicznych) trzonu paleozoicznego. Takim elementem wynoszonym w tym czasie był prawdopodobnie fałd łysogórski i południowa część synkliny bodzentyńskiej, czyli obszar położony w granicach ŚPN z najwyższymi twardzielcowymi pasmami: Łysogórami i Pasmem Klonowskim (Kowalczewski, Kowalski, 2000; Kowalski, 1995a, b, 2000).

Efekty poziomych przemieszczeń mas skalnych są widoczne w przebiegu pasm wzniesień. Stanowiące wschodnią część Pasma Klonowskiego odosobnione masywy góry Psarskiej i Miejskiej Góry (ryc. 3) zostały odseparowane 
od głównego pasma jako bloki tektoniczne, które, ulegając poziomym przesunięciom wzdłuż uskoków przecinających poprzecznie struktury fałdowe paleozoiku świętokrzyskiego w kierunku południowym, zostały morfologicznie uformowane w obecnej postaci izolowanych wzniesień (Kowalski, 2000a, b). Podobnie został ukształtowany skrajnie zachodni odcinek Pasma Pokrzywiańskiego, który tworzy izolowaną górę Chełmową. Wymienione izolowane masywy mają budowę zbliżoną do Pasma Klonowskiego, lecz na obszarze ich występowania dolnodewońskie serie piaskowcowe i piaskowcowo-łupkowe południowego skrzydła synkliny bodzentyńskiej są zapewne pocięte gęstszą siecią uskoków, wzdłuż których nastąpiło rozczłonkowanie Pasma Klonowskiego. W kierunku południowym zostało także przesunięte, w stosunku do Łysogór, Pasmo Jeleniowskie występujące już poza otuliną Świętokrzyskiego Parku Narodowego.

Badania geologiczne (m.in. geofizyczne) wykazują, że zróżnicowanie wysokościowe - falistość osi grzbietów Łysogór i Pasma Klonowskiego - zostało spowodowane obecnością poprzecznych uskoków, na których uformowały się przełęcze. W takich miejscach szybsza dezintegracja odpornych piaskowców kambryjskich doprowadziła do lokalnego obniżenia osi grzbietów (Kowalczewski i in., 1989; Kowalski, 2000).

\section{STRUKTURA PODLOŻA A ROZMIESZCZENIE GOLOBORZY I OSUWISK}

Specyfiką Łysogór i swoistym symbolem Świętokrzyskiego Parku Narodowego sa gołoborza (ryc. 3) - pokrywy blokowe utworzone na stokach i grzbiecie pasma w warunkach klimatu peryglacjalnego ostatniego glacjału i do tej pory nie pokryte roślinnością (Kotański, 1959; Klatka, 1962). Większą jednorodnością litologiczną północnego stoku Łysogór (rzadszym spękaniem i większą grubością ławic) można tłumaczyć większy zasięg gołoborzy na tym stoku, w stosunku do stoku południowego, aczkolwiek w holocenie istotnym czynnikiem warunkującym ich zanik i - tym samym - zmieniającym ich udział na stokach południowych i północnych, stały się warunki mikroklimatyczne determinowane przez ekspozycję (Kobendza, 1939; Huruk, 1986). Morfologia pól gołoborzy, a zwłaszcza rozmiary jęzorów gruzowych, wskazują na większą dynamikę blokowisk w okresie ich formowania na północnym skłonie Łysogór. Zdaniem niektórych badaczy jęzory gruzowe występujące poniżej blokowisk naszą cechy strukturalne, które mogą wskazywać na ich współczesny ruch (Jaśkowski i in., 2002).

Rozmieszczenie pól gołoborzy w Łysogórach jest tłumaczone obecnością poprzecznych uskoków w kambryjskich piaskowcach kwarcytowych, gdzie miała zachodzić lokalnie szybsza ich dezintegracja, przy czym efekty tego procesu są odmiennie interpretowane przez różnych autorów. Zdaniem Łyczewskiej (1972) oraz Kowalskiego (2000) obecność uskoków oraz - przede wszystkim - ruchów neotektonicznych na liniach tych uskoków przyczyniła się i nadal przyczynia do rozwoju pól gołoborzy, podczas gdy Sedlak (1964) uważał, że gołoborza w Łysogórach są najlepiej rozwinięte właśnie poza strefami tektonicznymi, bowiem w obrębie tych stref piaskowce są zbyt silnie spękane, by tworzyć pokrywy blokowe.

Do innych ruchów masowych, modelujących stoki pasm na obszarze ŚPN, należy osuwanie pakietów skalnych, które ogranicza się tylko do nielicznych i niewielkich obszarów na północnym skłonie Pasma Klonowskiego. Osuwiska konsekwentne warstwowe (ześlizgowe) występują na północnych stokach Bukowej Góry, Psarskiej Góry i Miejskiej Góry. Ich powstanie można tłumaczyć bardzo łatwym ześlizgiem warstw skalnych w sytuacji, gdy powierzchnia poślizgu jest równoległa do powierzchni stoku (Rączkowska, Rączkowski, 1999; Łajczak, 2014).

\section{SKAŁKI I JASKINIE}

Skałki należą do najciekawszych i najbardziej reprezentatywnych form rzeźby terenu na obszarze ŚPN i od dawna były opisywane w publikacjach krajoznawczych lub postulujących ochronę prawną tego terenu (Massalski, 1927, 1951, 1967; Czarnocki, 1928, 1932; Kotański, 1959; Rozborski, 2009), jednak rzadko stanowiły przedmiot badań i obserwacji naukowych (Klatka, 1962; Urban, 2016; Urban, Górnik, 2017). Skałki występujące na terenie parku są zbudowane z górnokambryjskich piaskowców kwarcytowych formacji z Wiśniówki oraz dolnodewońskich piaskowców formacji zagórzańskiej i są najczęściej zlokalizowane w grzbietowych partiach Łysogór oraz Pasma Klonowskiego (ryc. 3). Osiagają wysokość od kilku do kilkunastu metrów i mają kształty nieregularnych kopuł, grzęd skalnych, ostróg lub pochylonych stołów skalnych, rzadziej ambon czy platform. Formy te są efektem plejstoceńskich procesów peryglacjalnych, które spowodowały szybkie usuwanie materiału zwietrzelinowego i odsłanianie powierzchni zwięzłych skał podczwartorzędowego podłoża (Urban, 2016).

Skałki grzbietowe i przygrzbietowe w większości reprezentują strukturalne elementy rzeźby, bowiem ich powstanie było warunkowane budową geologiczna. Najbardziej charakterystycznymi formami strukturalnymi są grzędy skalne Agaty i Widnej Skałki na grzbiecie Łysogór, a także ściana i grzęda skalna na bocznym grzbiecie Chełmca (na południe od Łyśca - Łysej Góry), które stanowią wychodnie kilku twardzielcowych, najbardziej-odpornych na wietrzenie ławic skalnych w obrębie serii piaskowcowej tworzącej grzbiet. Mają więc wydłużenie dokładnie takie same, jak rozciąłość warstw (ryc. 6), zaś jedną z powierzchni bocznych grzęd tworzą powierzchnie ławic, podczas gdy druga jest wycięta wzdłuż powierzchni ciosowych. Jednak powierzchnie ciosowe tylko w pojedynczych przypadkach (Agata - ryc. 6B) mają kierunki zgodne z kierunkiem rozciagłości skałek, zazwyczaj zaś biegną skośnie do rozciągłości grzbietu (ryc. 6D-G). Podobnie dwie przywierzchowinowo-stokowe grupy skałkowe, zbudowane z piaskowców dolnodewońskich - skałki na Bukowej Górze oraz na Górze Miejskiej - reprezentują wychodnie najbardziej odpornych na denudację ławic, wyciętych wzdłuż powierzchni strukturalnych (ciosowych). Powierzchnie stropowe tych ławic stanowią powierzchnie górne stołów i platform skalnych, pochylonych zgodnie z nachyleniem stoku, podczas gdy powierzchnie boczne są wycięte wzdłuż płaszczyzn ciosowych (ryc. 7A-D). Różnice wykształcenia i sytuacji przestrzennej skałek kambryjskich i dewońskich (porównaj ryc. 6A, C oraz 7A, B, D) wynikają z odmiennej litologii piaskowców oraz ich różnic strukturalnych. Piaskowce dewońskie, występujące w grubszych ławicach oraz wykazujące rzadsze spękanie ciosowe, moga tworzyć duże, stabilne stoły skalne na stokach górskich. Natomiast podobne formy, utworzone z gęsto spękanych 


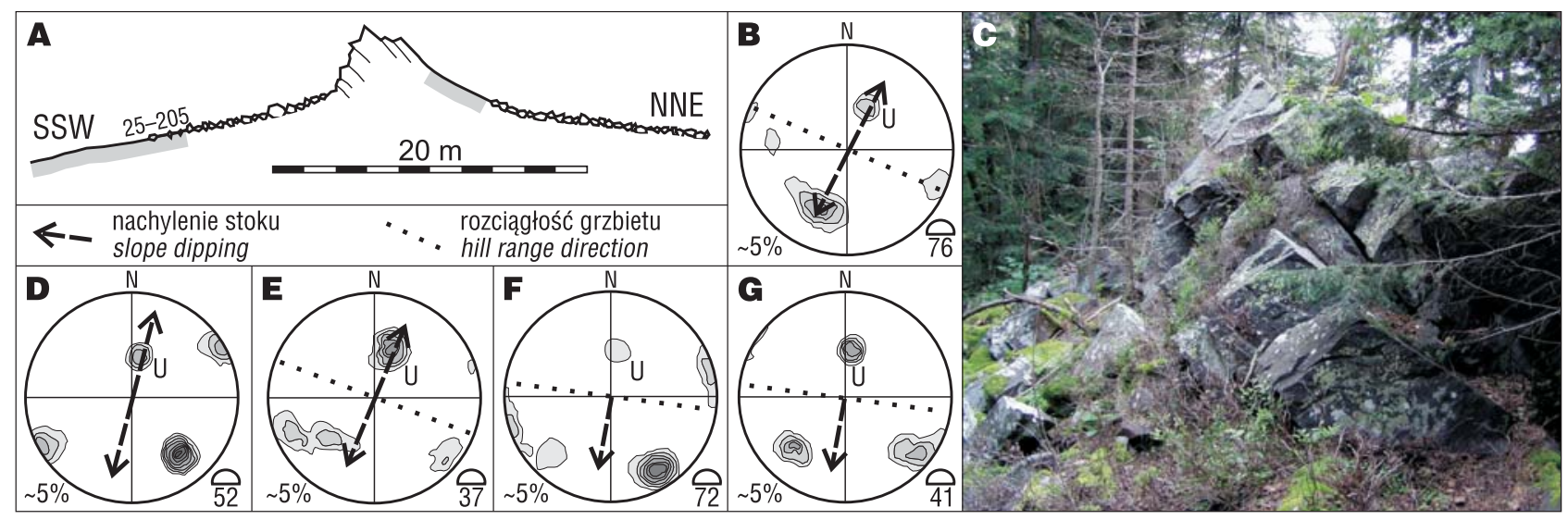

Ryc. 6. Uwarunkowania strukturalne skałek na grzbiecie Łysogór. A - profil morfologiczny skałki Agaty wzdłuż linii o azymucie $25-205^{\circ}$ (szary pasek oznacza występowanie gleby); B - diagram konturowy ciosu i uławicenia w obrębie Agaty (odzwierciedlenie na płaszczyznę poziomą przecięć linii normalnych do mierzonych powierzchni z półkulą górną) z oznaczeniem ilości pomiarów (76) oraz odległości izolinii (ok. 5\%), U - uławicenie; C - grzęda skalna Agaty widziana od strony wschodniej (fot. J. Urban); D - diagram konturowy ciosu i uławicenia w obrębie Białej Skałki (oznaczenia jak na ryc. B); E - diagram konturowy ciosu i uławicenia w obrębie Widnej Skałki (oznaczenia jak na ryc. B); F i G - diagramy konturowe ciosu i uławicenia w obrębie skałek na Chełmcu (oznaczenia jak na ryc. B) Fig. 6. Structural constraints of crags within the Łysogóry ridge. A-morphological profile along the azimuth direction of $25-205^{\circ}$ (grey belt is soil); $\mathbf{B}$ - contour diagram of joints and bedding planes in the Agata rock crest (projection of normals to measured planes on the upper hemisphere reflected on horizontal surface) with number of measurements (76) and isoline density (about 5\%), U - spatial situation of bedding planes; $\mathbf{C}$ - Agata rock crest visible from the east (photo by J. Urban); D - contour diagram of joints and bedding planes in the Biała Skałka crag (symbols as in Fig. B); $\mathbf{E}$ - contour diagram of joints and bedding planes in the Widna Skałka crag (symbols as in Fig. B); $\mathbf{F}$ and $\mathbf{G}$ - contour diagrams of joints and bedding planes in the Chelmiec crags (symbols as in Fig. B)

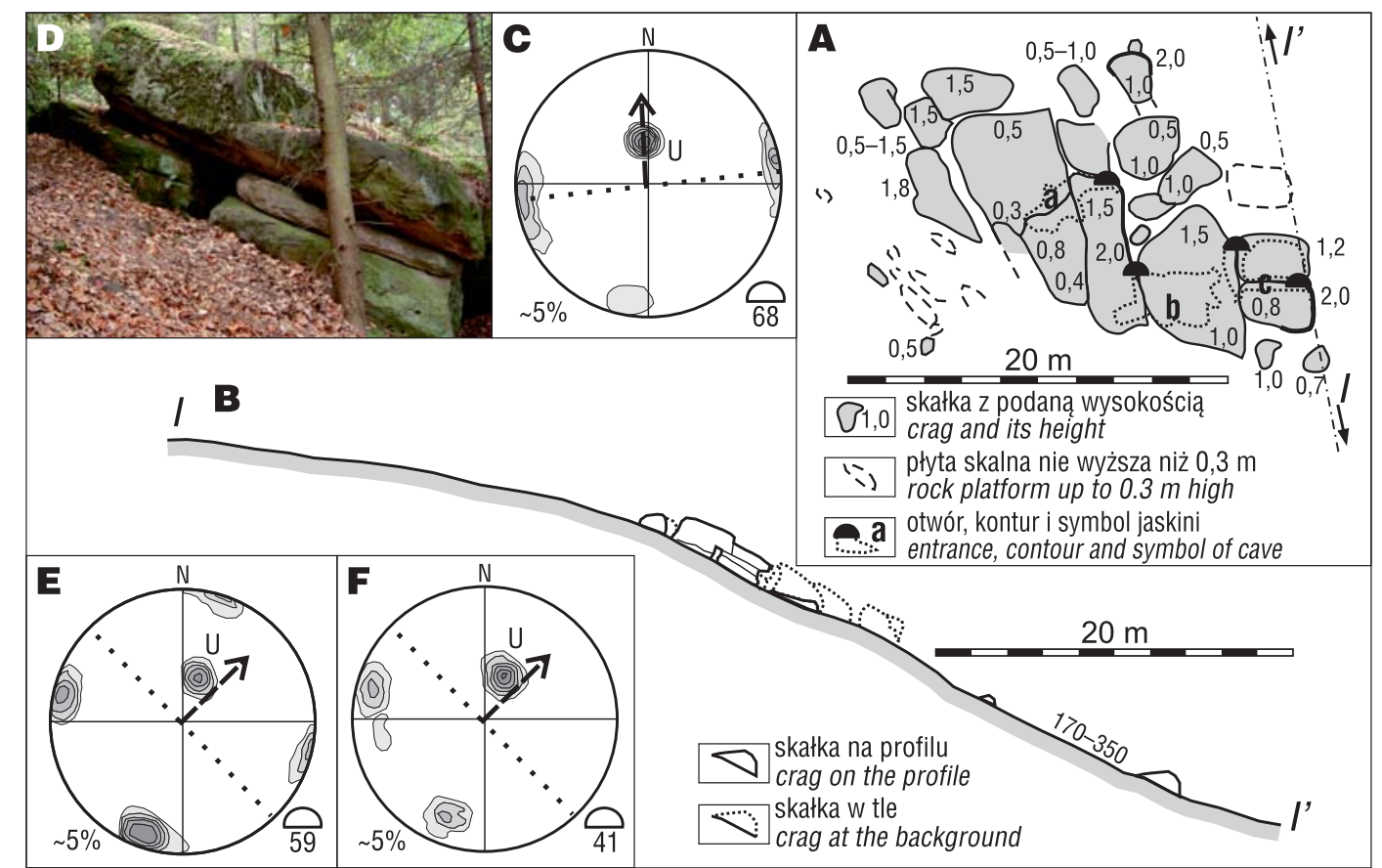

Ryc. 7. Uwarunkowania strukturalne skałek zbudowanych z piaskowców dolnodewońskich. A-plan skałek na Górze Miejskiej; nazwy obiektów jaskiniowych: a - Podgórski Schron, b - Miejski Schron, c - Szczelina Bodzentyńska; B - profil morfologiczny skałek na Górze Miejskiej wzdłuż linii zaznaczonej na planie A (oznaczenia jak na ryc. 6); C - diagram konturowy ciosu i uławicenia skałek na Górze Miejskiej (konstrukcja i oznaczenia jak na ryc. 6); D - pochylony stół skalny ze wschodnim otworem Szczeliny Bodzentyńskiej rozwartym w rezultacie grawitacyjnego przesunięcia ławic (fot. J. Urban); $\mathbf{E}$ i $\mathbf{F}$ - diagramy konturowe ciosu i uławicenia w skałkach na Bukowej Górze (oznaczenia jak na ryc. C)

Fig. 7. Structural constraints on crags built of Lower Devonian sandstones. A-map of crags at the Góra Miejska site; names of caves: a - Podgórski Schron, b - Miejski Schron, c - Szczelina Bodzentyńska; B - morphological profile along the line shown on the map (Fig. A) (symbols - see Fig. 6); C - contour diagram of joints and bedding planes in crags at the Góra Miejska site (construction and symbols the same as in Fig. 6); D - tilted rock table with the eastern entrance of Szczelina Bodzentyńska cave widened due to gravity-induced shift of rock beds; $\mathbf{E}$ and $\mathbf{F}$ - contour diagrams of joints and bedding planes at the Bukowa Góra site (symbols as in Fig. C) 
i cienkoławicowych piaskowców kambryjskich, ulegały szybkiej dezintegracji, w związku z czym formy skałkowe o kształcie grzęd utrzymały się jedynie na spłaszczonych grzbietach (Urban, 2016).

Strukturalne są również, bo wycięte wzdłuż powierzchni ciosowych, dwa z trzech niewielkich obiektów jaskiniowych w skałkach na Górze Miejskiej: Szczelina Bodzentyńska (długości $6 \mathrm{~m}$ ) i Podgórski Okap (5 m) (ryc. 7A). Zwłaszcza ta pierwsza jaskinia, będąca w części szczeliną poszerzoną grawitacyjnie, w części zaś - szczeliną wietrzeniowa, jest wyraźnie warunkowana kierunkami ciosowymi w piaskowcach (Urban, Kasza, 2009).

Za formy uwarunkowane strukturalnie można uznać również skalną kulminację Łysicy oraz nieodległą Białą Skałkę (ryc. 6D), które stanowią rozczłonkowane kopuły skalne wieńczące grzbiet Łysogór. W tym przypadku strukturalne uwarunkowania ma ich lokalizacja na grzbiecie, który jest wychodnią najodporniejszej serii piaskowcowej w obrębie górnokambryjskiej formacji z Wiśniówki, natomiast kształt skałek, który jest generalne owalny i w niedużym stopniu nawiązuje do rozciągłości warstw. Niewielki związek pomiędzy litologią i położeniem przestrzennym warstw a wykształceniem form rzeźby jest widoczny w przypadku grupy niewielkich ambon i stołów (w tym licznych bloków) skalnych na Łyścu, a także dwu grup grzęd i ostróg skalnych w najniższej części stoku Łyśca (Łysej Góry) w Słupi Nowej, po południowej i północnej stronie drogi ze Słupi na Święty Krzyż. We wszystkich tych przypadkach skałki stanowią twardzielcowe elementy rzeźby, ale ich zależność od litologii oraz innych struktur (ciosu) jest trudna do ustalenia przy braku odsłonięć sąsiednich warstw. W ich przypadku znaczenie mogło mieć natomiast antropogeniczne odsłanianie spowodowane dawna, współcześnie trudno już czytelną, eksploatacją piaskowców.

\section{PRZELOMY}

Obniżenia po obu stronach Łysogór i Kraińskiego Grzbietu łączą przełomy rzeczne: Lubrzanki (Kowalski, 1988) oraz Słupianki, których przebieg nawiązuje do uskoków tektonicznych. Te przełomy stanowią element charakterystycznego dla omawianego obszaru, kratowego systemu sieci dolinnej, którego rozwój następował wraz z formowaniem rzeźby rusztowej grzbietów. Kowalski (1988) wyróżnił dwa etapy formowania przełomu Lubrzanki - starszy w neogenie, w którym dominowała epigeneza oraz młodszy z dominacją antecedencji. Od początku formowania przełomu główny grzbiet Gór Świętokrzyskich był poprzecznie rozcinany wzdłuż uskoku mającego najpewniej waryscyjskie jeszcze założenia, ale odmłodzonego podczas ruchów alpejskich. Umożliwiło to ukierunkowanie odpływu z północnego podnóża Łysogór na południe.

Z kolei uformowanie przełomu Słupianki, rozwiniętego wzdłuż uskoku poprzecznego, gdzie nastąpiło przesunięcie na południe Pasma Jeleniowskiego w stosunku do Łysogór (Kowalski, 2000), umożliwiło odpływ wód z południowego podnóża tych pasm w kierunku północnym. Przyczyny tych różnokierunkowych drenaży wód w przełomach zlokalizowanych po obu stronach Łysogór nie zostały dotąd wyjaśnione.

\section{PODSUMOWANIE I WNIOSKI}

W dotychczasowych badaniach nad rzeźbą strukturalną obszaru Świętokrzyskiego Parku Narodowego i jego otuliny uwaga była skierowana głównie na relacje między litologią podłoża a wykształceniem głównych elementów rzeźby tego obszaru. Bardzo wyraźne litologiczne uwarunkowanie przebiegu grzbietów i obniżeń nie wyklucza jednak, zdaniem niektórych badaczy (Kowalski, 1988, 2000), wpływu paleogeńskiej i neogeńskiej tektoniki na wzajemne położenie hipsometryczne dużych stref synklinalnych i antyklinalnych. Ponadto wykazano wpływ uskoków na przebieg grzbietów i dolin (Kowalski, 1995a, 2000; Studencki, 1995), a także na deniwelacje w obrębie osi grzbietów Pasma Klonowskiego i Łysogór. Zwracano również uwagę na wpływ drobnych struktur tektonicznych na ukształtowanie stoków (Kowalczewski i in., 1989; Kowalczewski, Kowalski, 2000; Kowalski, 1995b, 2000). Kowalski (2000) zasugerował neotektoniczną przebudowę rzeźby w centralnej części regionu świętokrzyskiego, w nawiązaniu do zróżnicowanej odporności skał podłoża. Przedstawił także strukturalnie uwarunkowany schemat rozwoju przełomu rzeki Lubrzanki w Łysogórach (Kowalski, 1988).

Strukturalność elementów rzeźby niższego rzędu jest różna i różnie interpretowana. Łysogórskie gołoborza (i zarośnięte już pola i jęzory blokowiskowe) utworzyły się na wychodniach serii piaskowcowych, jednak peryglacjalne procesy stokowe spowodowały ich rozprzestrzenienie, rozmywając cechy strukturalne, natomiast związek tych zjawisk z tektoniką nieciagłą jest interpretowany odmiennie przez różnych autorów. Formy skałkowe, które ze swej natury mają litologiczne uwarunkowania, w większości ale nie wszystkie - odzwierciedlają także inne cechy strukturalne geologicznego podłoża.

W świetle dotychczasowej wiedzy, dotyczącej strukturalnych uwarunkowań rzeźby obszaru Świętokrzyskiego Parku Narodowego i otuliny, pozostaje otwarte pytanie odnoszące się do oceny czasoprzestrzennej roli struktury geologicznej w rozwoju rzeźby parku, zwłaszcza w odniesieniu do jej formowania podczas zlodowaceń plejstoceńskich. Dotyczy to szczególnie przekształceń głównych elementów rzeźby w wyniku ruchów tektonicznych. Możliwość taką stwarza wykorzystanie NMT (Numeryczny Model Terenu) o dużej rozdzielczości do analiz morfostrukturalnych rzeźby ŚPN.

\section{LITERATURA}

CZARNOCKI J. 1928 - Rezerwat w Górach Świętokrzyskich ze stanowiska potrzeb geologii. Zabytki Przyrody Nieożywionej Ziem Rzeczpospolitej Polskiej, 1: 30-44.

CZARNOCKI J. 1932 - Mniej znane zabytki geologiczne Gór Świętokrzyskich. Ochrona Przyrody, 12: 74-81.

CZARNOCKI J. 1950 - Geologia regionu łysogórskiego w związku z zagadnieniem złoża rud żelaza w Rudkach. Pr. Państw. Inst. Geol. CZARNOCKI J. 1957 - Prace geologiczne. T. II, Geologia regionu łysogórskiego. Stratygrafia i tektonika Gór Świętokrzyskich, z. 1. Inst. Geol., Prace - XVIII.

FILONOWICZ P. 1962 - Szczegółowa Mapa Geologiczna Polski 1 : 50 000, ark. Bodzentyn. Wyd. Geol., Warszawa.

FILONOWICZ P. 1966 - Szczegółowa Mapa Geologiczna Polski $1: 50$ 000, ark. Nowa Słupia. Wyd. Geol., Warszawa.

FILONOWICZ P. 1968 - Objaśnienia do Szczegółowej Mapy Geologicznej Polski 1 : 50 000, ark. Nowa Słupia. Wyd. Geol., Warszawa. FILONOWICZ P. 1969 - Objaśnienia do Szczegółowej Mapy Geologicznej Polski 1 : 50 000, ark. Bodzentyn. Wyd. Geol., Warszawa. 
GILEWSKA S. 1972 - Wyżyny Śląsko-Małopolskie. [W:] Klimaszewski A. (red.), Geomorfologia Polski, t. I Polska Południowa. Góry i Wyżyny. Wyd. Nauk. PWN, 232-239.

GILEWSKA S. 1991 - Rzeźba. [W:] Starkel L. (red.), Geografia Polski. Środowisko przyrodnicze. PWN, 248-296.

GRANICZNY M., MIZERSKI W., PIĄTKOWSKA A. 2005 - Lineaments interpreted at the radar images and the digital elevation model within the Palaeozoic rocks of the Holy Cross Mts. Prz. Geol., 53 (10/2): 949-955.

HAJDUKIEWICZ M., ROMANYSHYN I. 2017 - Oszacowanie dokładności punktów wysokościowych na NMT masywu Łysicy z pomiarów ALS. Structure and Environ., 9 (2): 125-132.

HURUK S. 1986 - Gołoborza Świętokrzyskiego Parku Narodowego Chrońmy Przyr. Ojcz., 46 (1): 14-22.

JAROSIŃSKI M., POPRAWA P., ZIEGLER P. 2009 - Cenozoic dynamic evolution of the Polish Platform. Geol. Quart., 53 (1): 3-26.

JAŚKOWSKI B., KOWALSKI B., SOŁTYSIK R. 2002 - Geneza i wiek pokryw wietrzeniowych na stokach Łysej Góry w Górach Świętokrzyskich. Pr. Inst. Geogr. AŚ w Kielcach, 8: 107-138.

KARNKOWSKI P.H. 2008 - Regionalizacja tektoniczna Polski - Niż Polski. Prz. Geol., 56 (10): 895-903.

KLATKA T. 1962 - Geneza i wiek gołoborzy łysogórskich. Acta Geogr. Lodziendzia, 12.

KLATKA T. 1965 - Geomorfologia Gór Świętokrzyskich. Roczn. Gleboznaw., 15, dodatek: 129-162.

KLIMASZEWSKI M. 1958 - Rozwój geomorfologiczny terytorium Polski w okresie przedczwartorzędowym. Prz. Geogr., 30 (1): 3-43.

KOBENDZA R. 1939 - Gołoborza i ich stosunek do lasu w Górach Świętokrzyskich. Instytut Badawczy Lasów Państwowych, Rozprawy i Sprawozdania, seria A, 43.

KONDRACKI J. 2000 - Geografia regionalna Polski. Wyd. 2 poprawione, PWN, Warszawa.

KONON A. 2008 - Regionalizacja tektoniczna Polski - Góry Świętokrzyskie i regiony przyległe. Prz. Geol., 56 (10): 921-926.

KOTAŃSKI Z. 1959 - Łysogóry. [W:] Przewodnik geologiczny po Górach Świętokrzyskich, t. 2. Wyd. Geol., Warszawa: 341-360.

KOWALCZEWSKI Z. 2000a - Litostratygrafia, paleogeografia, facje i tektonika kambru świętokrzyskiego (zagadnienia podstawowe i stan znajomości). Pr. Inst. Geogr. WSP w Kielcach, 4: 7-66.

KOWALCZEWSKI Z. 2000b - Wybrane problemy geologii Pasma Głównego Gór Świętokrzyskich w świetle badan geofizycznych. Posiedzenia Nauk. Państw. Inst. Geol., 56: 138-141.

KOWALCZEWSKI Z., KOWALSKI B. 2000 - Zarys budowy geologicznej. [W:] Cieśliński S., Kowalkowski A. (red.), Monografia Świętokrzyskiego Parku Narodowego. ŚPN, Bodzentyn-Kraków: 51-100.

KOWALCZEWSKI Z., KOWALSKI B., JANIEC J. 1989 - Wpływ budowy geologicznej na rzeźbę Pasma Klonowskiego. Biul. Państw. Inst. Geol., 362: 65-95.

KOWALCZEWSKI Z., ROMANEK A., STUDENCKI M. 2000 - Mapa geologiczna odkryta paleozoiku Gór Świętokrzyskich 1 : 200000 (mat. niepubl.). Państw. Inst. Geol., Oddział Świętokrzyski w Kielcach. KOWALCZEWSKI Z., ŻYLIŃSKA A., SZCZEPANIK Z. 2006 - Kambr w Górach Świętokrzyskich. [W:] Skompski S., Żylińska A. (red.), LXXVII Zjazd Naukowy PTG, Ameliówka k. Kielc 28-30 czerwca 2006, „Procesy i zdarzenia w historii geologicznej Gór Świętokrzyskich”. Państw. Inst. Geol., Warszawa: 4-27.

KOWALSKI B. 1988 - Warunki powstania i rozwój przełomowego odcinka doliny Lubrzanki przez główne pasmo Gór Świętokrzyskich w trzeciorzędzie. Prz. Geogr., 60 (3): 329-351.

KOWALSKI B. 1995a - Przejawy młodej aktywności tektonicznej w Dolinie Kielecko-Łagowskiej w Górach Świętokrzyskich i jej wpływ na układ sieci wodnej. Prz. Geol., 43 (4): 307-316.

KOWALSKI B. 1995b - Wpływ młodych ruchów tektonicznych na odkształcenia paleogeńskiej powierzchni zrównania w Górach Świętokrzyskich. [W:] Materiały II Zjazdu Geomorfologów Polskich w Sosnowcu. Wyd. UŚ, Sosnowiec: 39-41.

KOWALSKI B. 2000 - Rzeźba. [W:] Cieśliński S., Kowalkowski A (red.), Monografia Świętokrzyskiego Parku Narodowego. ŚPN, Bodzentyn-Kraków: 107-128.

KOWALSKI B., JAŚKOWSKI B. 1986 - Litologiczno-strukturalne uwarunkowania teras krioplanacyjnych na stokach masywu Łysej Góry w Górach Świętokrzyskich. Prz. Geogr., 58 (4): 493-514.

LENCEWICZ S. 1934 - Le massif hercynien des Łysogóry (S-te Croix) et ses enveloppes. [W:] Comptes rendus du Congres Intern. de Géogr. 1934, Varsovie, Excur. B 3/1.

LENCEWICZ S. 1936 - Surface d'aplanissement tertiaire dans le monts Łysogóry. [W:] Comptes rendus du Congres Intern. de Géogr. 1934, Varsovie, 2: 492-496.

LENCEWICZ S. 1957a - Wyżyna Kielecko-Sandomierska. [W:] Pisma wybrane z geografii fizycznej Polski. PWN, Warszawa: 53-102.
LENCEWICZ S. 1957b - Hercyński masyw Gór Świętokrzyskich i jego pokrywy. [W:] Pisma wybrane z geografii fizycznej Polski. PWN, Warszawa: $157-188$.

ŁAJCZAK A. 2014 - Operat Ochrony Zasobów Geomorfologicznych. [W:] Plan Ochrony Świętokrzyskiego Parku Narodowego i Obszaru Natura 2000 Łysogóry na lata 2013-2033 (mat. niepubl.). Dyr. ŚPN, Bodzentyn.

ŁYCZEWSKA J. 1972 - Niektóre problemy czwartorzędu świętokrzyskiego. Rocz. Pol. Tow. Geol., 42 (1): 81-92.

MALEC J. 2006 - Sylur w Górach Świętokrzyskich. [W:] Skompski S. Żylińska A. (red.), LXXVII Zjazd Naukowy PTG, Ameliówka k. Kielc 28-30 czerwca 2006, ,Procesy i zdarzenia w historii geologicznej Gór Świętokrzyskich”. Państw. Inst. Geol., Warszawa: 36-50.

MASSALSKI E. 1927 - Bukowa Góra. Ziemia, 2: 18-19.

MASSALSKI E. 1951 - Najcenniejsze pod względem dydaktycznym zabytki skalne Gór Świętokrzyskich. Zabytki Przyrody Nieożywionej, 1/4: 41-43.

MASSALSKI E. 1967 - Góry Świętokrzyskie. Wiedza Powszechna. Warszawa.

MASTELLA L., MIZERSKI W. 2002 - Budowa geologiczna jednostki łysogórskiej (Góry Świętokrzyskie) na podstawie analizy zdjęć radarowych. Prz. Geol., 50 (9): 697-712.

MIZERSKI W. 1991 - Ewolucja tektoniczna regionu Łysogórskiego Gór Świętokrzyskich. Rozpawy UW, 362: 1-141.

MIZERSKI W. 2004 - The Holy Cross Mts in the Caledonian, Variscan and Alpine cycles - major problems, open questions. Prz. Geol., 52 (8/2): 774-779.

NARKIEWICZ M., GRAD M., GUTERCH A., JANIK T. 2010 - Crustal seismic velocity structure of southern Poland: preserved memory of a pre-Devonian terrane accretion at the East European Platform margin. Geol. Mag., 148 (2): 191-210.

NARKIEWICZ M., RACKI G., SKOMPSKI S., SZULCZEWSKI M. 2006 - zapis procesów i zdarzeń w dewonie i karbonie Gór Świętokrzyskich. [W:] Skompski S., Żylińska A. (red.), LXXVII Zjazd Naukowy PTG, Ameliówka k. Kielc 28-30 czerwca 2006, „Procesy i zdarzenia w historii geologicznej Gór Świętokrzyskich”. Państw. Inst. Geol., Warszawa: $51-77$.

NAWROCKI J., DUNLAP J., PECSKAY Z., KRZEMIŃSKI I., ŻYLIŃSKA A., FANNING M., KOZLOWSKI W., SALWA S. SZCZEPANIK Z., TRELA W. 2007 - Late Neoproterozoic to Early Palaeozoic palaeogeography of the Holy Cross Mts. (Central Europe); an integrated approach. J. Geol. Soc., London: 164: 405-423.

OLĘDZKI J. 1976 - Wpływ zróżnicowania budowy geologicznej na rzeźbe w Górach Świętokrzyskich. Pr. Stud. Inst. Geogr. UW, 17, Geogr. Fiz., 6: $1-66$.

RADŁOWSKA C. 1967 - Charakterystyka geomorfologiczna Gór Świętokrzyskich. Problemy Zagosp. Ziem Górskich, 4 (17): 51-77.

RADŁOWSKA C. 1968 - On the morphogenesis of European highlands based on the field studies in the Holy Cross Mountains. Geograph. Pol., 14: $67-76$.

RACZKKOWSKA Z., RACZKOWSKI W. 1999 - Plan Ochrony Zasobów Geomorfologicznych. [W:] Plan Ochrony Świętokrzyskiego Parku Narodowego (mat. niepubl.). Dyr. ŚPN, Bodzentyn.

ROZBORSKI T. 2009 - Próba określenia genezy skałek na Bukowej Górze. Piękne, rzadkie, chronione, cz. II. Skarżyskie Zesz. LOP, 11: 140-146.

SALWA S. 2006 - Wstępna charakterystyka strukturalno-petrograficzna fyllitów z Podmąchocic w regionie łysogórskim Gór Świętokrzyskich. Prz. Geol., 54 (6): 513-520.

SEDLAK W. 1964 - Teoria łysogórskich gołoborzy. Rocz. Filozof. KUL, 12 (3): 45-67.

SLYMAKER O. 2004 - Mountain geomorphology. [W:] Goudie A.S. (red.), Encyclopedia of Geomorphology, t. 2. J-Z. Routledge, Taylor \& Francis Group, London: 701-703.

SOLON J., BORZYSZKOWSKI J., BIDŁASIK M., RICHLING A., BADORA K., BALON J., BRZEZIŃSKA-WÓJCIK T., CHABUDZIŃSKI Ł, DOBROWOLSKI R., GRZEGORCZYK I., JODŁOWSKI M., KISTOWSKI M., KOT R., KRĄŻ P., LECHNIO J., MACIAS A., MAJCHROWSKA A., MALINOWSKA E., MIGOŃ P., MYGA-PIĄTEK U., NITA J., PAPIŃSKA E., RODZIK J., STRZYŻ M., TERPIŁOWSKI S., ZIAJA W. 2018 - Physico-geographical mesoregions of Poland: verification and adjustment of boundaries on the basis of contemporary spatial data. Geograph. Pol., 91 (2): 143-170.

STARKEL L. 1972 - Karpaty zewnętrzne. [W:] Klimaszewski M. (red.), Geomorfologia Polski, cz. I - Polska Południowa, PWN Warszawa: $52-115$.

STUDENCKI M. 1995 - Wyniki interpretacji lotniczych zdjęć radarowych wykonanych w regionie świętokrzyskim. Rocznik Świętokrzyski KTN, 12: 47-62. 
SZULCZEWSKI M. 1995 - Depositional evolution of the Holy Cross Mountains (Poland) in the Devonian and Carboniferous-a review. Geol. Quart., 39: 471-488.

TRELA W. 2006 - Ordowik w Górach Świętokrzyskich, zapis stratygraficzny i sedymentacyjny. [W:] Skompski S., Żylińska A. (red.), LXXVII Zjazd Naukowy PTG, Ameliówka k. Kielc 28-30 czerwca 2006, „Procesy i zdarzenia w historii geologicznej Gór Świętokrzyskich”. Państw. Inst. Geol., Warszawa: 28-35.

URBAN J. 2014 - Cechy rzeźby strukturalnej Gór Świętokrzyskich oraz południowo-wschodniej części Niecki Nidziańskiej. Prz. Geol., 62 (1): 44-50.

URBAN J. 2016 - The geological constraints of the development of sandstone landforms in Central Europe, a case study of the Świętokrzyskie (Holy Cross) Mountains, Poland. Geomorph., 274: 31-49.

URBAN J., GACGOL J. 2008 - Geological heritage of the Świętokrzyskie (Holy Cross) Mts (Central Poland). Prz. Geol., 56 (8/1): 618-628.
URBAN J., GÓRNIK M. 2017 - Some aspects of lithological and exogenic control of sandstone morphology, the Świętokrzyskie (Holy Cross) Mts. Case study, Poland. Geomorph., 295: 773-789.

URBAN J., KASZA A. 2009 - Genetical types of the caves in sandstones of the Świętokrzyskie (Holy Cross) Mountains, Central Poland. [W: Proceedings of the $10^{\text {th }}$ International Symposium on Pseudokarst, 29.042.05.2008, Gorizia: 43-52.

WALCZOWSKI A. 1968 - Objaśnienia do Szczegółowej Mapy Geologicznej Polski w skali 1 : 50 000, ark. Łagów. Wyd. Geol., Warszawa. WRÓBLEWSKI T. 1976 - Rzeźba Gór Świętokrzyskich. Roczn. Świętokrz. Kiel. Tow. Nauk., 5: 9-22.

WRÓBLEWSKI T. 2000a - Charakterystyka orograficzna i toponimia. [W:] Cieśliński S., Kowalkowski A. (red.), Monografia Świętokrzyskiego Parku Narodowego. ŚPN, Bodzentyn-Kraków: 45-50.

WRÓBLEWSKI T. 2000b - Ochrona georóżnorodności w regionie świętokrzyskim. Państw. Inst. Geol., Warszawa. 